\title{
ON the Function of NAME IN IRISH AND \\ Slavonic Written Incantation Tradition ${ }^{1}$
}

\author{
Tatyana Mikhailova
}

\section{Introduction}

The main aim of the present paper is to compare Irish and Russian popular charm traditions. While an element of subjectivity is involved in such a comparison, it nevertheless has validity due to the fact that a kind of "naïve Christianity" was superimposed in both traditions on a highly developed priestly pagan culture and an existing body of traditional popular beliefs. This superimposition created a specific symbiosis of cultures both in Ireland and in Russia. We draw the reader's attention here not only to the so-called 'double-faith' (dvoyeveriye), but also to a specific attitude to magic, especially to the magic of the spoken or written word. The words of a Russian annalist, that "the Russian people like magic and witchcraft" (Русские люди прелестни и падки на волхвование) could be applied to the Irish people too, and a specific kind of Irish 'women-magic' (amaitecht) is reminiscent of the Russian 'wizard-women' (вещие женки). ${ }^{2}$

The present investigation has the further aim of developing a universal model of the functioning and pragmatics of 'magic texts', both inside a local culture and in general, against the backdrop of the stable belief in the 'power of the word'. But before we proceed to investigate that, we have to start with the problem of terminology.

\section{The incantation.}

By 'incantation' or 'charm' (from Latin canticum 'song, incantation') we understand, following J. Roper (Roper 2004: 1), "the verbal element of vernacular magic practice". It is assumed here that this definition is better than that suggested by the Brothers Grimm, who proposed to define 'charms' as "verbal formulas, of Christian and non-Christian form, used outside of a Church context, and to which are attributed a supernatural effect, mostly

\footnotetext{
The publication of the present article, as well as the participation of Prof. Mikhailova in the Colloquium, was facilitated by a grant from the British Academy under the Visiting Professorship/Fellowship scheme. Prof. Mikhailova was a British Academy Visiting Professor at the Research Institute for Irish and Celtic Studies, University of Ulster, Coleraine, in June 2005.

2 All translations, unless otherwise noted, are mine.
} 
of a protective, healing kind" (cf. Roper 2004: 1). Although the preferred definition may be rather broad, it is by virtue of this breadth that a wider comparative study may be pursued, with regard not only to the folk charmtradition, but also to medieval manuscripts created within monastic milieu (in Ireland and in Slavonic countries), as well as the pre-Christian pagan 'charm-material' of the ancient world.

\section{The concept of the 'name'}

With regard to the traditional culture of incantations (or charms), we propose to distinguish between two different uses of the term 'name': the 'background name' and the 'subject name'.

\subsection{The 'background name'}

By 'background name' we mean the use of the names of Christian saints (including local saints from apocryphal traditions) as well as personages of pagan beliefs; all of these create a specific background to the magic formula. The background demonstrates the orientation and the religious identity of the compiler and of the user of the magic text. As we understand matters, our material - especially the Russian and Slavonic material in general - provides us with numerous examples of the confusion between naive Christianity and popular superstitions and beliefs, which may not be really pagan, but may demonstrate the adoration of the forces of nature. The following analysis of the 'background names' illustrates our idea. Consider, for example, the following charm against fever:

I, the godly slave (name), I apply to you, and I ask you, great helpers Kosma and Damian, Luka and Paul, tell me, why the bare-headed women are coming from the Ocean, why they are wandering in our world, why they deprive us of sleep and food, why they drink our blood, why they are eating like worms our stomach and liver, why they saw our yellow bones? (Russian text in Majkov 1994: no. 107).

Jesus is coming from heaven with a golden cross. He was washed by the dawn, he was dried by the sun, he was covered by the cross and locked by his lock... (A charm against a thief; Russian text in Protsenko 1998: 223).

These examples demonstrate the specific 'fabulas' or 'scenarios' of Russian charms, representing mini-plots. The world of Russian charms illustrates, in fact, the amorphous mind of the compiler, who cannot separate Christianity from popular beliefs. But we could hardly present these beliefs as pagan. 
We could add that in Russian, and in Slavonic charms in general, there exists a large group of personages without names. Sometimes, these anonymous individuals receive a specific name through the individualisation of an appellative, e.g. a wind can be called 'Wind, son of Wind', or 'Storm, son of Storm'. We are not sure if a name of this kind is a real proper name, but remember it should be borne in mind that the individualisation of the appellative represents a universal way of forming gods' names (cf. Celtic Epona 'The Horse', Artiona 'The Bear', Abona 'The River', Goibniu 'The Smith' etc.).

When we turn to the nomina propria of Russian charms, we discover that each text illustrates its strict orientation either towards Christianity or towards the adoration (and personification) of the forces of nature. This is a subject which requires fuller treatment here.

In the collection of Russian charms by L. Majkov 164 texts out of 372 (44\%) contain 'background names'. ${ }^{3} 147$ charms demonstrate their Christian origin, and 20 charms are invocations to the forces of nature (with names). Only three texts straddle the divide, being both oriented towards Christianity and expressive of the adoration of the forces of nature. This is what happens in the following example:

Встану я, раб Божий, благословясь, пойду, перекрестясь, из избы в избу, из дверей в двери, из ворот в ворота, под восток под восточную сторону; под восточной стороной ходит матушка утренняя заря Мария, вечерняя заря Маремьяна, мать сыра земля Пелагея и сине море Елена. Я к ним приду поближе, поклонюсь им пониже... (A charm against insomnia, Majkov 1994: no. 56).

I will rise, a Godly slave, with a blessing, I will go, blessing myself, from a hut to another hut, from the door to another door, from the gates to other gates, to the East, to the Eastern side. The daybreak, Mariya, walks along the Eastern side, [as well as] the sunset, Marem'yana, [and] the earth, Pelageya, and the blue sea, Elena. I will come closer to them; I will bow lower before them ...

Матушка заря вечерняя Дарья, утренняя Марея, полуночная Макарида, как вы потухаете, поблекаете, денные и ночные, так бы и болезни и скроби в рабе Божием (имя рек) человеке потухли бы и поблекли денные, ночные и полуночные. Аминь (Majkov 1994: no. 236).

Mother, the sunset, Dar'ya, the morning, Mareya, the midnight, Makarida, as you get dim and fade away, daily or nightly, so all the diseases and the

\footnotetext{
Not taking into account the general tradition invocation formula 'Lord Jesus Christ' etc.
} 
troubles of the Godly slave (name) would also get dim and fade away, daily and nightly and in the midnight. Amen.

Firstly, let us note that in the above citation all the forces of nature have Christian names. And secondly, the forces of nature generally have different names in different charms (the sunset may be called Mariya, Elena, Ul'yana etc.).

The compiler of the charm does not very often employ the names of Christ, the Virgin Mary and other Christian saints together with the names of personified forces of nature. In the Majkov-collection we have found only three cases of such parallel usage, for example:

под красное солние, под светел месяи, под утреню зарю Марию, под вечернюю Маремьяну, ко Кияну морю, на Кияне море Златырь камень, святая апостольская церковь, в апостольской церкви свят престол, на святом престоле сидит Михайло архангел, да Егорий храбрый (Majkov 1994: no. 194).

... to the red Sun, to the bright Moon, to the daybreak, Maria, to the sunset, Marem'yana, to the sea, Kiyan (Ocean); in the sea Kiyan [there stands a] Zlatyr-rock, the holy apostolic Church, [there is] a golden altar in the apostolic church, and on this altar there sits the archangel Michael and Yegorij the brave.

As Ryan (2004:123) points out, one can see that:

in the matter of charms the mixture of elements is not so simple, and not just Christian/non-Christian, but a matter of selection from all the possible levels of 'religious' or 'magical' knowledge available to the reciter of the charm.

In modern Russian 'neo-paganism' we were not able to find any Christian background names. This tradition tries to find and to use the names of Slavonic pagan deities, both real and old, as well as new (pseudo-pagan) names, taken from different literary sources. Quite surprisingly, New Year in this pagan tradition was celebrated on the $1^{\text {st }}$ November, and this day was called Samhagan (transliterated in Russian as Самхаган).

But the model of these neo-pagan charms reminds us of the same pattern, and in this context we can see the relevance and the importance of the 'background names' as identity-markers. We could compare different charms used for protection against bleeding as a further example:

На мори на Кияни, на острове на Буяни, на камне на высоком стоит гробница, в гробнице лежит красная девица; ты встань, востань, 
красная девушка, возьми иглу линевую, ты вздень нитку шелковую, зашей рану кровавую (Majkov 1994: no. 143).

On the sea, Kiyan, on the island, Buyan, on the high rock there stands a coffin, in the coffin there lies a beautiful girl; stand up, rise up, beautiful girl, take a needle with a thick, thread a silk thread, close a bleeding wound.

На море на Окияне, на острове на Буяне лежит бел горюч камень. На сем камне стоит изба таволоженная, стоит стол престольный. На сем столе сидит красна девица. Не девица сие есть, а Мать Пресвятая Богородица. Шьет она, вышивает золотой иглой, ниткой шелковою. Нитка, оборвись, кровь запекись, чтобы крови не хаживати, а тебе телу не баливати (Majkov 1994: no. 144).

On the sea, on the ocean, on the island, Buyan, there lies a white hot rock. On this rock there stands a hut made of meadow-sweet, [and] there stands a holy table. There sits a beautiful girl on this table. But she is not a girl, but the Mother Our Lady. She embroiders in silk with a golden needle. Thread, break, blood, stay, the blood should not be walking, the body should not be ill.

На море на Окияне, на острове на Буяне лежит камень; на том камне сидела Пресвятая Богородица, держала в руке иглу золотую, вдевала нитку шолковую, зашивала рану кроваву (Majkov 1994: no. 141).

On the sea, on the ocean, on the island, Buyan, there lies a rock; Our Lady used to sit on this rock, she used to hold a golden needle in her hand, she used to put a silk thread through it, she used to sew up a bleeding wound.

На море-окияне, на острове Буяне стоит камень бел-горюч, сидит на нем красная девица, швея-мастерица, берет иглу булатную, вдевает нитку шелковую, рудо-желтую, зашивает раны кровавые. Заря-зарница, Даждьбога сестра, помоги мне запечь, запереть рань кровавые на брате или сестре (имярек) (Diachkova 2002: 68).

On the sea, on the ocean, on the island, Buyan, there stands a white hot rock. A beautiful girl is sitting on this rock; [she is a] qualified seamstress, she takes an iron needle, puts in a silk [and] crimson-yellow thread, she covers bloody wounds. The daybreak, Dajdbog's sister, help me to cover the bloody wounds on the brother or sister (name).

The invocation of forces of nature represents a universal element of all charms and needs no further commentary. But let us note, however, that the invocation of Christ, Mary and also of local saints in folk charms and incantations of Christian countries represents a substitute for an appeal to other forces, invoked in the charm in its earlier form. We can recall that in Germany Christian prayers, including apocryphal ones, were recommended to be used when gathering herbs instead of 'the Devil's spells' (Murdoch 
1988: 359). We assume that the Church did not forbid incantations and charms because the use of spoken words in healing was practised both by Christ and by saints. This practice, however, contradicts the Russian witch courts of the sixteenth-seventeenth centuries, when a person could have been accused for having only some sheets of paper with 'white zagovors', that is, apocryphal curative prayers.

As the list of 'background names' demonstrates, Irish folk charms provide a strict Christian dimension. In this regard they are close to the late Slavonic tradition, e.g. Czech (see recent collection in Welmezova 2004). The 'plot-charms' are rare in Ireland, and if we encounter any small 'stories', they refer to the apocryphal Christian tradition and not to the mysterious world with 'Rock Alatyr', 'Sea Ciyan', 'Big Oak' etc. A good example is a charm against fever (ortha an fiabhrais):

Neart Mhuire agus a mic. Cúnamh ón Spiorad Naomh. Dhá láimh gheala Chriost $i$ gcoinnibh na haicíde seo ó aniuv go bliain ó aniuv agus anocht féin amháin lé Dia. Nuair a chonnaic Críost an Chros tháinig air crith cos agus lámh. D'fhiosraig an Giúdach de cioca fiabhras do bhi air nú pláig. Do fhreagair Críost an guth agus duairt sé ná raibh air fiabhras, crith, ná pláig. Agus an té adéarfadh na focail sin, Muire agus Íosa, nár bhaol dó fiabhrús ná miavrús do thógaint go brách (Ó Duilearga 1973: 119-120).

Strength of Mary and her Son. Help of the Holy Spirit. The two white hands of Christ against this disease from today until a year from today and tonight only with God. When Christ saw the Cross, a shaking of feet and hands came upon him. The Jew asked him whether he had a fever or a plague. Christ answered the voice and he said that he had neither fever, shaking, nor plague. The person who would say those words, Mary and Jesus, would never risk contracting fever or bad-illness (?).

A blood-charm (ortha na fola) provides further evidence of the phenomenon:

Leanbh a rugadh i stábla Bhethlehem agus do baisteadh i n-abhainn Judgment, i n-abhainn dhoimhin dhioghbhálaigh. Bhi an leanbh lag cúlbásach cé gur sheasaimh sé agus gur shnáimh sé; nár fearr do sheasaimh sé agus do shnáimh sé ná stadfa[i]dh do chuid fola agus feola! In-ainm an Athar agus an Mhic agus an Spioraid Naomh. Amen (Ó Súilleabháin 1932: 356).

A child was born in Bethlehem and he was baptised in the river of Judgment, in a deep and dangerous river. This child was feeble and $\langle\ldots>$, although he stood and he swam, were it not better that he stood up and swam than that 
your blood and flesh should cease to be (?). In the name of the Father, the Son and the Holy Spirit. Amen. ${ }^{4}$

Another useful example is a 'delivery-charm':

\begin{abstract}
A bhean, beir do leanbh / Mar rug Anna Muire /Mar rug Muire Dia / Gan mairtriú, gan daille / Gan easba coise ná láimhe
\end{abstract}

Woman, bear your child as Anne bore Mary, as Mary bore God, without disfigurement nor blindness or lack of foot or hand (Ó Súilleabháin 1977: 43).

One could find many examples of this kind and all of them will be of the same type. We have not been able to find any invocation to the personified forces of nature in Irish traditional folk charms, and neither have we found background names like 'Earth Ul'yana' or 'Sunset Elena'. And it is, we think, understandable if we consider these incantations, like Ó Súilleabháin did, as 'apocryphal folk prayers' (Ó Súilleabháin 1977: 85).

A specific feature of Irish and Scottish charms is the invocation to local saints, especially to St. Brigid. She possesses a specific protective power, and she can give force to protective amulets, used by women during labour. For example:

Bride! Bride! Come in, Thy welcome is truly made. Give thou relief to the woman. And give the conception to the Trinity (Ross 1976: 127).

The 'background names' employed in the charms could serve not only to indicate the religious identity of the performer, but also as an indicator of any sub-ethnos (indicated by the names of local saints) and of the function of the charm - whether it is a love magic charm, or a protective one, a healing one etc., as all of these functions were associated with their special 'protector saints' in the Christian apocryphal tradition. Russian zagovors have been closely investigated from this point of view (Kliaus 2000, Judin 1997). We can give here an interesting example of the importance of a 'background name'. In a small study devoted to a "Church-Slavonic prayer against the devil”' (Konzal 1992), a Czech scholar Vaclav Konzal concluded after his detailed analysis of the list of 'background names' that it was composed by St. Methodius. In Konzal's opinion, this text, preserved in

\footnotetext{
4 The following motif - 'the water of Jordan stood, so shall thy blood' - is universal in European charms (cf. for example, English and Germanic parallels in Roper 2004). Russian and Baltic parallels also exist, but the focus of my analysis here is on the use of names and not on the genesis of motifs. The idea of the common origin of charms remains a mere conjecture. A more likely explanation is that of a 'wondering motif'.
} 
the thirteenth century manuscript, was composed in Moravia, presumably between 870 and 873 , when St. Methodius was arrested in a monastery. On the basis of St. Methodius's knowledge of the list of saints from Western Christian tradition, V. Kozel supposes that the author of this text was familiar with it, but was rather inclined towards the Eastern Church (as arguments in favour of his hypothesis, he mentions the languages of the prayer, the Eastern liturgical formulas etc., - cf. Kozel 2002: 100-101).

\subsection{The 'subject name'}

By the 'subject name' we understand any proper name in the text of a charm which transforms a 'receipt' (the term of G. Gager, see Gager 1992) of a magical text in potentia into a real magical performance. But if we turn to the problem of the use of the so-called 'subject names' in Slavonic and Gaelic traditional charms, we observe a certain difference between the two traditions. We suppose that this difference is very important from the point of view of the typology of charms in modern Eastern and Western traditions. Russian charms (as well as other Slavonic and Balkan, e.g. Romanian, charms) require the obligatory introduction of the proper name in the 'body' of the text (cf. the traditional formula - "the slave of God N"), but Western charms (e.g. English, French, Germanic, Baltic etc.) are usually used without this formula. We understand that our attempt to explain this phenomenon needs a wider and deeper analysis on the basis of data from across the European charm tradition. It is at this stage too early to try to answer the question where exactly the border lies between the two charm traditions, the first one characterised by the use of proper names and the second one in which the texts remain anonymous. However, let us provide some suggestions with regard to this problem.

The introduction of a 'subject name' in the text of a charm, or of a magical text in a wider sense, supposes a single performance of this text. In Old Irish tradition we can find also examples of magical texts, focused on a single performance and, as we can add, on a single composition. Here we recall the well-known Irish 'satire' (áer) that served as the weapon of the Irish poet against the authority of the king. We may assume that the well-known glamm dicinn composed against king Caer was composed once only and performed once only. But the actual text of this satire (called 'a black charm') is preserved in Cormac's Glossary, and represents not a 
historical testimony, but rather a literary composition. Two different recensions of Cormac's Glossary contain two different texts of this incantation, and therefore we cannot be sure if the story about the poet Nede and the king Caer represents a true historical event. But when we turn to reliable historical evidence, e.g. archaeological testimonies of the use of magic texts (the curse tablets and protective amulets of the classical tradition), we find the obligatory use of proper names in the body of these texts. And it is quite logical in this respect because a charm without a proper name represents a message without an address.

Let us note that in a Church Slavonic prayer against the devil, the author, supposedly St. Methodius, presumes the future use of the text with a proper name. This is obvious where in some passages of the prayer the word 'name' is mentioned: in this instance each performer must introduce his own name:

Азъ ... рабъ Божии (имя) припадаю ко весем святымъ моляся имъ...

It is me, slave of God (the name) I address to all saints praying to them...

(Kozel 2002: 107).

Furthermore, the author provides the text with the following title "Prayer against the devil and the black demons to all saints, the mode of saying it and of calling one's own name" (bold T.A., in original Church Slavonic: “и имя свое нарекаши...”).

We encounter a similar situation in the written charm-tradition. A text with a 'subject name' represents a real magical text (curse tablets, amulets, Old Russian nauz etc.). On the contrary, a text without a proper name does not represent a charm, but rather a receipt for a future charm. For example, Greek magical papyri represent not 'charms' in the proper sense, but rather a collection of receipts of charms:

King Osiris, King Osiris Onnophris, who arouses the whole earth, that you may arouse the heart of $\mathrm{NN}$ whom $\mathrm{NN}$ has borne ${ }^{5}$, that I may know what is in her heart for me, for NN whom NN has borne, on this day (Betz 1996: 40).

We could compare this 'receipt' with an inscription on a small clay pot, dating to the third century A.D., also found in Egypt:

Let Matrona, to whom Tagene gave birth, whose stuff you have, including the hairs of her head, love Theodoros, to whom Techosis gave birth (Gager 1992: 101)

\footnotetext{
5 The name of mother, because the father was considered as 'inceterus'.
} 


\section{Conclusion}

We can conclude that the Western charm tradition, including Irish, simply has lost the idea of the obligatory use of subject names and began to use 'receipts' as magical texts, which originally contained no magic at all. We recall that the medieval manuscript tradition of charms conscientiously employed 'subject names'. Consider, for example, the following Middle English charm against some eye disease: "...that fro this time foreward thou neuer greue more the ye of this man N" (bold T.A., cit. Olsan 2004: 61).

Also, reference may be made here to an Old English charm 'To find a lost object':

The cross of Christ was buried in the earth, and it was found by St. Helena the queen, in the holy service of the miracle. Likewise this lost object $\mathrm{N}$ (here one must name the object) must be found (Storms 1948: 213).

The Eastern (Slavonic and Balkan) charm tradition is more conservative and more archaic. Our interpretation of the problem is likely to require further analysis, particularly in relation to the problem - under-researched so far - of the use of proper names (in the terminology of this article, 'subject' names) in comparative studies of the traditional European charms. We hope that our 'subjective' Irish-Russian comparison will be a stimulus for future research into the subject.

Moscow State University 
TATYANA MIKHAILOVA

\section{SUMMARY \\ ТАТЬЯНА МИХАЙЛОВА}

\section{ФУНКЦИЯ ИМЕНИ В ПИСЬМЕННОЙ ИРЛАНДСКОЙ И СЛАВЯНСКОЙ ЗАГОВОРНОЙ ТРАДИЦИИ}

КАЖДОЕ СЛОВО, ВЫНЕСЕННОЕ В ЗАГЛАВИЕ, НУЖДАЕТСЯ В ОСОБОЙ ИНТЕРПРЕТАЦИИ. ИССЛЕДОВАНИЕ В ЦЕЛОМ НАПР АВЛЕНО НА РАЗР АБОТКУ ГЛОБАЛЬНОЙ ПР ОБЛЕМЫ ТИПОЛОГИИ МАГИЧЕСКОГО ТЕКСТА КАК ОСОБОГО (НО - ПОСТОЯННОГО!) ФЕНОМЕНА КУЛЬТУРЫ. ПОД ИМЕНЕМ В ЗАГОВОР Е МЫ ПОДР АЗУМЕВАЕМ ДВА ТИПА УПОТР ЕБЛЕНИЯ ИМЕН СОБ СТВЕННЫХ, УСЛОВНО НАЗВАННЫХ НАМИ - «Ф ОНОВОЕ ИМЯ» И «СУБЪЕКТНОЕ ИМЯ〉. В ПЕРВОМ СЛУЧАЕ РЕЧЬ ИДЕТ ОБ ИМЕНАХ КАК ХРИСТИАНСКИХ (И АПОКР ИФ ИЧЕСКИХ), ТАК И ЯЗЫЧЕСКИХ МИФ ОЛОГИЧЕСКИХ ПЕР СОНАЖЕЙ, СОЗДАЮЩИХ СПЕЦИФИЧЕСКИЙ «ФОН» МАГИЧЕСКОЙ ФОРМУЛЫ. ЕСТЕСТВЕННО, В МАТЕР ИАЛЕ, К КОТОР ОМУ МЫ ОБР АЩАЕМСЯ В ПЕРВУЮ ОЧЕРЕДЬ (ОСОБЕННО - СЛАВЯНСКОМ, И В ЧАСТНОСТИ РУССКОМ), ПРОВЕДЕНИЕ ЧЕТКОЙ ГРАНИЦЫ МЕЖДУ ЯЗЫЧЕСТВОМ И «НАИВНЫМ ХРИСТИАНСТВОМ» ОКАЗЫВАЕТСЯ НЕВОЗМОЖНЫМ. ДЕТАЛЬНЫЙ АНАЛИЗ НАБ ОР А СООТВЕТСТВУЮЩИХ «Ф ОНОВЫХ ИМЕН» ХОР ОШО ИЛЛЮСТР ИР УЕТ НАШ ТЕЗИС. В ТО ЖЕ ВРЕМЯ В КАЧЕСТВЕ «ФОНОВОГО ИМЕНИ» МОГУТ ТАКЖЕ ИСПОЛЬЗОВАТЬСЯ УНИКАЛЬНЫЕ ДЛЯ ПОЛЬЗОВАТЕЛЯ ОБЪЕКТЫ - НАЗВАНИЯ СВЕТИЛ, СТИХИЙ, «ДОЧЕРЕЙ МОР Я〉 (ИР ЛАНДСКАЯ ЛОР ИКА) И Т.П. ПОД СУБЪЕКТНЫМ ИМЕНЕМ МЫ ПОДР АЗУМЕВАЕМ УНИКАЛЬНОЕ ИМЯ СОБСТВЕННОЕ, ОБОЗНАЧАЮЩЕЕ ЛИЦО, ДЛЯ (ПРОТИВ) КОТОРОГО ЕДИНОКР АТНО ВОСПР ОИЗВОДИТСЯ МАГИЧЕСКИЙ ТЕКСТ. ПИСЬМЕННАЯ ТР АДИЦИЯ, С ОДНОЙ СТОРОНЫ, МОЖЕТ БЫТЬ ТАК НАЗЫВАЕМОЙ НАИВНОЙ ФИКСАЦИЕЙ УСТНОГО ТЕКСТА, ПРЕДПОЛОЖИТЕЛЬНО - С ЦЕЛЬЮ ДАЛЬНЕЙШЕГО ВОСПРОИЗВЕДЕНИЯ, ДЛЯ ЗАПОМИНАНИЯ. С ДРУГОЙ СТОРОНЫ, ПИСЬМЕННАЯ ТР АДИЦИЯ МАГИЧЕСКОГО ТЕКСТА ПРЕДПОЛАГАЕТ СОЗДАНИЕ ОСОБЫХ АРТЕФАКТОВ (ТАБЛИЧКИ С ПРОКЛЯТИЯМИ, АМУЛЕТЫ, ДР .Р УССКИЕ «НАУЗЫ» И ПР ОЧ.), В КОТОР ЫХ ИМЯ ИСПОЛНЯЕТ ВАЖНЕЙШУЮ ФУНКЦИЮ: СОБСТВЕННО СОЗДАНИЯ МАГИЧЕСКОГО, ПР ИНЦИПИАЛЬНО УНИКАЛЬНОГО ОБЪЕКТА (СР. ПЛОТИЙ, КАЭР, МИХЕЙ ИЗ НОВГОРОДСКОЙ БЕРЕСТЯНОЙ ГРАМОТЫ И ПРОЧ.). ОСОБЫЙ ИНТЕРЕС ПРЕДСТАВЛЯЮТ ТЕКСТЫ, В КОТОРЫХ УПОТРЕБЛЕНО МЕСТОИМЕНИЕ 《Я», ПРЕДПОЛАГАЮЩЕЕ ВОЗМОЖНОСТЬ ВОСПР ОИЗВОДИМОСТИ И ПОЛИНАПРАВЛЕННОСТИ ТЕКСТА (В РУССКОЙ ТРАДИЦИИ РАСПРОСТРАНЕНО МАЛО). ПОД ПОНЯТИЕМ «ЗАГОВОР» МЫ ПОДР АЗУМЕВАЕМ И СОБСТВЕННО ЗАГОВОРНЫЙ ТЕКСТ КАК ФЕНОМЕН ЯЗЫКА, И ОСОБОЕ МАГИЧЕСКОЕ ДЕЙСТВИЕ, СОПРОВОЖДАЮЩЕЕСЯ ИЗГОТОВЛЕНИЕМ ОБЪЕКТА С НАНЕСЕННЫМИ НА НЕМ ПИСЬМЕНАМИ (НАПРИМЕР, МАГИЧЕСКИЕ РУНЫ В ДРЕВНЕЙ СКАНДИНАВИИ). СОПОСТАВЛЕНИЕ СРЕДНЕВЕКОВОЙ ИР ЛАНДСКОЙ И РУССКОЙ ТР АДИЦИЙ ОБУСЛОВЛЕНО ТИПОЛОГИЧЕСКИМ СХОДСТВОМ ПО ВЫШЕУКАЗАННЫМ РУБР ИКАМ - ИМЯ, ПИСЬМЕННАЯ ТР АДИЦИЯ, ЗАГОВОР . 